\title{
A multivariate approach to analyze the spatial-temporal variation of limnological parameters of the reservoir of the Curuá-Una hydroelectric plant
}

The construction of reservoirs for hydroelectric plants (HP) began in the 1960s and is currently an integral part of the objectives of economic expansion plans in Brazil. The Curuá-Una HP was the first HP constructed in the central Amazon. Due to the great importance of this reservoir for limnological studies in the Amazon the objective of this study was to analyze and quantify the percentage of spatial-temporal variation of limnological variables upriver of the reservoir of the CuruáUna hydroelectric plant. Sampling was conducted between 2016 and 2017. The limnological variables analyzed were water transparency, conductivity, turbidity, dissolved oxygen, $\mathrm{pH}$, biological oxygen demand, nitrate, silica, total phosphorus, and chlorophyll-a. Principal components analysis was used to investigate patterns and the size of the gradient in the reservoir, and to select which spatial and temporal variables make significant contributions a canonical redundancy analysis (RDA) was conducted incorporating a partitioning of variance. PCA showed that the samples were seasonally grouped, and the first two axes explained $51.74 \%$ of the variability. The RDA and partition of variance showed that the spatial and temporal explanatory variables together explained $66 \%$ of the variability (time $=56 \%$, spatial $=10 \%$, time and spatial $=0 \%$, residual $=34 \%$ ). The results obtained suggest that the seasonal effect is responsible for $56 \%$ of the variability, and such changes in time are sufficient enough to alter the biological processes when environmental conditions are turbulent.

\section{Uma abordagem multivariada para analisar a variação espacial- temporal dos parâmetros limnológicos do reservatório usina hidroelétrica de Curuá-Una}

\begin{abstract}
A construção de reservatórios para usinas hidrelétricas (UHE) começou na década de 1960 e é atualmente parte integrante dos objetivos dos planos de expansão econômica no Brasil. A UHE de Curuá-Una foi a primeira construída na Amazôna central. Devido à grande importância deste reservatório para estudos limnológicos na Amazônia, o objetivo deste estudo foi analisar e quantificar o percentual de variação espaço-temporal de variáveis limnológicas a montante do reservatório da usina hidrelétrica de Curuá-Una. A amostragem foi realizada entre 2016 e 2017. As variáveis limnológicas analisadas foram: transparência da água, condutividade, turbidez, oxigênio dissolvido, pH, demanda bioquímica de oxigênio, nitrato, sílica, fósforo total e clorofila-a. Para investigar os padrões e o tamanho do gradiente ambiental foi utilizada uma análise de componentes principais (PCA). Para discriminar e selecionar quais as variáveis espaço-temporais que contribuem significativamente, realizou-se uma análise de redundância canônica (RDA) e uma partição de variância. A PCA mostrou que as amostras foram agrupadas sazonalmente, e os dois primeiros eixos explicaram $51,74 \%$ da variabilidade. A RDA e partição de variância demonstraram que as variáveis explicativas do espaço tempo, juntas explicam $66 \%$ (tempo $=56 \%$; espaço $=10 \%$; tempo+espaço $=0 \%$; resíduo $=34 \%$ ). Os resultados obtidos sugerem que o efeito sazonal é responsável por $56 \%$ da variabilidade, tais mudanças no tempo são suficientes para alterar os processos biológicos quando as condições ambientais são mais turbulentas.
\end{abstract}

Palavras-chave: Amazônia; Reservatório de Curuá-Una; Limnologia; Variação espaço-temporal.

Topic: Desenvolvimento, Sustentabilidade e Meio Ambiente

Reviewed anonymously in the process of blind peer.
Received: 05/10/2020

Approved: $26 / 11 / 2020$
Paulo Roberto Brasil Santos (iD)

Universidade Federal do Oeste do Pará, Brasil

http://lattes.cnpq.br/9558469007033186

http://orcid.org/0000-0003-2454-3061

paulobrasil pesca@hotmail.com

\section{Jéssica da Silva Azevedo}

Universidade Federal do Oeste do Pará, Brasil

http://lattes.cnpq.br/7432620928589582

ibioazevedo@gmail.com

Dávia Marciana Talgatti it

Universidade Federal do Oeste do Pará, Brasil

http://lattes.cnpq.br/3712448942978626

http://orcid.org/0000-0002-8277-9788

daviatalgatti@gmail.com

\author{
Edvaldo Junior de Souza Lemos (iD \\ Universidade Federal do Oeste do Pará, Brasi \\ http://lattes.cnpq.br/2974368476892162 \\ http://orcid.org/0000-0002-4370-3633 \\ edvaldo lemos@yahoo.com.br \\ Flávia Cristina Carvalho de Lima (iD) \\ Universidade Federal do Oeste do Pará, Brasil \\ http://lattes.cnpq.br/6228881728501774 \\ http://orcid.org/0000-0001-7057-2037 \\ quimica flavia@yahoo.com.br \\ Keid Nolan Silva Sousa (D) \\ Universidade Federal do Oeste do Pará, Brasil \\ http://lattes.cnpq.br/3553985889834657 \\ http://orcid.org/0000-0002-1152-1923 \\ keid.ufopa@gmail.com
}

Referencing this:

SANTOS, P. R. B.; AZEVEDO, J. S.; TALGATTI, D. M.; LEMOS, E. J. S.; LIMA, F. C. C.; SOUSA, K. N. S.. A multivariate approach to analyze the spatial-temporal variation of limnological parameters of the reservoir of the Curuá-Una hydroelectric plant. Revista Ibero Americana de Ciências Ambientais, v.11, n.6, p.479-491, 2020. DOI:

http://doi.org/10.6008/CBPC2179-6858.2020.006.0039 


\section{INTRODUCTION}

The increasing demand for electrical energy was a major reason for the construction of numerous reservoirs in Brazil during the $20^{\text {th }}$ century, and today there are 768 small, medium, and large hydroelectric projects installed in Brazil, a total which represents $75.39 \%\left(77,52310^{6} \mathrm{MW}\right)$ of the total electrical power generation capacity installed in the country (ANEEL, 2009). The construction of artificial reservoirs reached its maximum between the decades of 1960 to 1990, and currently is an integral part of the economic expansion objectives of Brazil. As a development strategy adopted by the Federal government during these decades, five hydroelectric dams were constructed in the Brazilian Amazon (FARIA, 2006). The Amazon region is the center of expansion of hydroelectric power plants (HP) of the country and has 18 new hydroelectric plant that will be or are already under construction on the Madeira River, Jirau and Santo Antonio (Rondônia) and Belo Monte (Pará) among other localities where thousands of fishermen may be affected (MORETTO et al., 2012; FEARNSIDE, 2016; SANTOS et al., 2017).

Diegues (2000) stated that the construction of hydroelectric dams and their respective reservoirs produces negative externalities in the ecosystem and promotes deforestation, contaminates hydrological resources, and modifies ecological and human communities that depend, directly or indirectly, on the natural resources in the vicinity of the dam. Despite these externalities, reservoirs are systems with high capacity for restructuring and self-organization, influenced by natural and artificial drivers that determine the circulation dynamic and thermal stratification, both resulting from climatological and hydrological regimes (TUNDISI et al., 2008), promoting a heterogeneity of physical and chemical gradients in horizontal and vertical axes (AGOSTINHO et al., 2006; OLIVEIRA et al., 2000).

Among the innumerous hydroelectric plants constructed in the Amazon, the Curuá-Una HP, constructed in 1977, was the first HP constructed in the interior of the Amazon forest (Brazil), and is located approximately $72 \mathrm{~km}$ south of the city of Santarém in the State of Pará, as part of the Tucuruí interconnected system. To the west of this HP are the primary tributaries of the Curuá-Una River: the Moju and Mojuí rivers, definided by Junk et al. (1981) as being clear water rivers. The geology of the majority of the region is composed of the Barreiras sedimentary formation of the Cretaceous-Tertiary, with acid, low nutrient soils (VIEIRA et al., 1999).

The stretch of the Curuá-Una River that is upriver from the HP dam created new environmental conditions that caused intense modifications in oxygen concentration, incidence of solar radiation, and nutrients, in comparison to the biotic communities present before and after the construction of the HP. Vieira et al. (1999) conducted a study in the reservoir of the Curuá-Una HP and demonstrated that the dam construction altered physical and chemical parameters such as transparency, temperature, $\mathrm{pH}$, electrical conductivity, and dissolved oxygen, and that these changes impacted the aquatic biota.

In this context the objective of the current study was to analyze and quantify the spatial-temporal variation of limnological variables during 12 months upriver of the reservoir of the Curuá-Una hydroelectric plant. 
A multivariate approach to analyze the spatial-temporal variation of limnological parameters of the reservoir of the Curuá-Una hydroelectric plant

\section{MATERIALS AND METHODS}

\section{Characterization of the Study Area}

The Curuá-Una dam is located on the Curuá-Una River at the Palhão waterfall $\left(2^{\circ} 50^{\prime}\right.$ South and $54^{\circ} 18^{\prime}$ West), $72 \mathrm{~km}$ southwest of the city of Santarém, State of Pará, Brazil. According to Fearniside (2004), the majority $(57,4 \%)$ of the reservoir is within the Curuá-Una watershed, with just a small portion which is located within the watersheds of other rivers, such as the Moju (11.7\%), Mojuí (4.4\%), and Poraquê (3.2\%), and also in several smaller streams (2.9\%). The reservoir was filled between January and May, 1977, and its surface area is $78 \mathrm{~km}^{2}$, longitudinal extension is $42 \mathrm{~km}$, residence time of water is between 20 and 75 days, and its volume is approximately 130 to $530 \times 10^{6} \mathrm{~m}^{3}$ (GUNKEL et al., 2003).

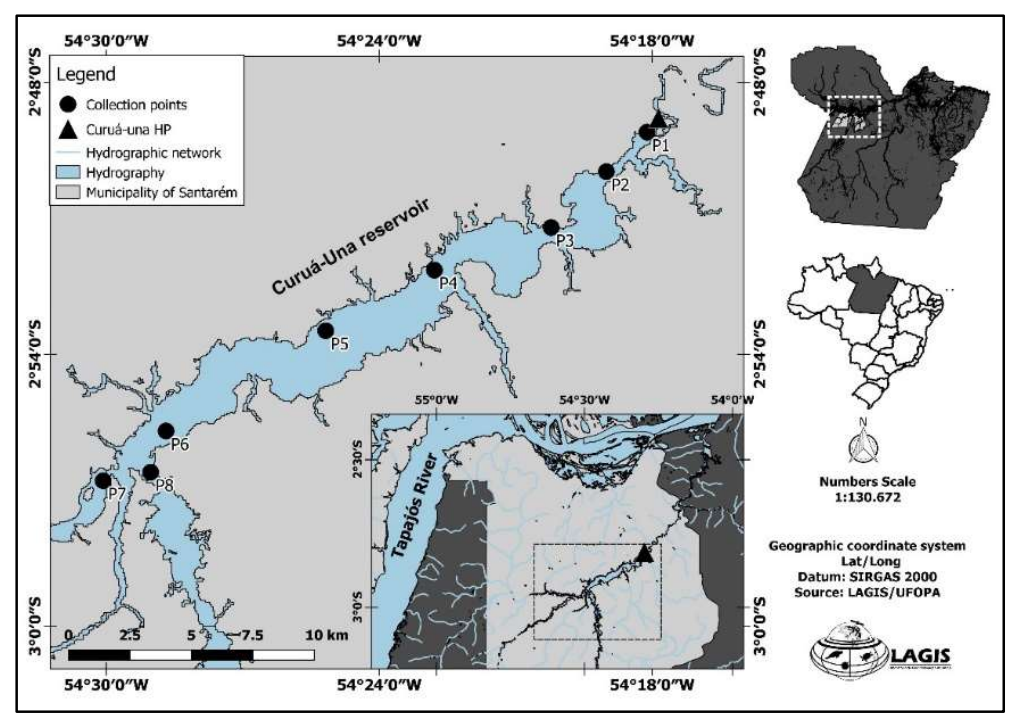

Figure 1: Map of the study area in the Curuá-Una reservoir.

\section{Characterization of the sample data}

Sample collection was conducted monthly between May 2016 and April 2017 at 8 (P1 to P8) collection stations in the reservoir totaling 96 samples in 12 months. The in situ environmental data taken were: depth $(\mathrm{m})$ measured with an eco sensor GARMIM ECHO 150, and water transparency $(\mathrm{m})$ using a Secchi disk. Additionally, $\mathrm{pH}, \mathrm{DO}$ - dissolved oxygen $\left(\mathrm{mg} \mathrm{L}^{-1}\right)$, conductivity $\left(\mu \mathrm{Sm}^{-1}\right)$, and temperature $\left({ }^{\circ} \mathrm{C}\right)$ were measured using a multiparameter sensor AKSO model AK88.

Turbidity (NTU), ammonia $\left(\mathrm{mg} \mathrm{L}^{-1}\right)$, nitrate $\left(\mathrm{mg} \mathrm{L}^{-1}\right)$, total phosphorus $\left(\mu \mathrm{g} \mathrm{L}^{-1}\right)$, silicates $\left(\mathrm{mg} \mathrm{L}^{-1}\right)$, chlorophyll-a $\left(\mu \mathrm{g} \mathrm{L}^{-1}\right)$, and biological oxygen demand - BOD $\left(\mathrm{mg} \mathrm{L}^{-1}\right)$ were sampled using $500 \mathrm{ml}$ and $1000 \mathrm{ml}$ polypropelene flasks that were placed at a depth of approximately $30 \mathrm{~cm}$, immediately refrigerated, and then transported to the Environmental Biology Laboratory of the Institute of Water Science and Technology of the Federal University of Western Pará - ICTA/UFOPA for analysis.

The international manual Standard Methods for the Examination of Water and Wastewater (APHA, 2012) was used to analyze BOD, nitrogen species, total phosphorus, and silicates. Turbidity was determined using a benchtop Policontrol AP 2000 series turbiditymeter. For the determination of chlorophyll-a the 
A multivariate approach to analyze the spatial-temporal variation of limnological parameters of the reservoir of the Curuá-Una hydroelectric

SANTOS, P. R. B.; AZEVEDO, J. S.; TALGATTI, D. M.; LEMOS, E. J. S.; LIMA, F. C. C.; SOUSA, K. N. S.

trichromatic method of Strickland et al. (1968) was used. Furthermore, all the methods cited above were conducted using a BIOSPECTRO model SP-220 UV-visible spectrophotometer. Rainfall data were obtained through the data collection platform (PCD) of the National Institute for Space Research - INPE/CRN/SINDA which maintains a meteorological station at the Curuá-Una HP.

\section{Data Analysis}

The first step in the analysis of the environmental variables was to conduct a Ranging standardization, the objective of which is to put the abiotic factors, which were measured in different units, into a common scale, thus allowing for comparisons between variables (LEGENDRE et al., 2012).

In order to investigate the patterns and the size of the environmental gradient a Principal Component Analysis (PCA) was conducted wherein the factorial axes were extracted from a correlation matrix. The determination of the number of significant components was determined using a Broken Stick test. The individual contribution of the environmental variables (original variables) were observed from the PCA Loadings (coefficients), and the significance of these Loadings was tested using bootstrappings (9999 permutations) (PERES-NETO et al., 2003).

Two matrices of explanatory variables were constructed, one for time using a Dummy variable (binary categorical data) for variation in rainfall, using as a base the studies by Fisch et al. (1998), Vieira et al. (1999) and Vale et al. (2016). In this matrix we established the dry season as July through September, the transition season as May to June and October to November, and the rainy season as December to April.

For the spatial data a spatial matrix was constructed from spatial descriptors using the Principal Coordinates of Neighborhood Matrices (PCNM) method, which transforms pairs of geographic coordinates into a truncated Euclidean distance matrix (BORCARD et al., 2002). The generated autovectors produce a spectral decomposition of the spatial relations between all the sample points generating variables that represent different spatial scales, from large scale (the first autovectors generated by the PCNM) to smaller scale (the last autovectors generated by the PCNM) (BORCARD et al., 2002; GRIFFITH et al., 2006). Complementing this matrix are the Dummy categorical variables of the three areas which are composed of: Area 1 points P1 and P2; Area 2 points P3, P4 and P5; Area 3 points P6, P7 and P8.

A Canonical Redundancy Analysis (RDA) in order to discriminate and select which spatial and time variables most significantly contribute to the variability in the limnological data from the reservoir using a forward selection method (Monte Carlo test: 9999 permutations) (LEGENDRE et al., 2012). The next step was a partitioning of the variance using the protocol proposed by Borcard et al. (1992), and complemented by Peres-Neto et al. (2006), estimating four fractions of variance of the spatial and temporal variability for the environmental variables of the reservoir.

In order to analyze the significant differences between the spatial and temporal variables a two-way ANOVA was conducted with Factor 1 as the temporal variables and Factor 2 as the spatial variables. Additionally, the significance of the interaction between the spatial and temporal factors was done and the 
A multivariate approach to analyze the spatial-temporal variation of limnological parameters of the reservoir of the Curuá-Una hydroelectric

Tukey post hoc test at a significance level of $\alpha \leq 0.05$ was applied.

Analyses were conducted using the $\mathrm{R}$ computational environment version 3.4 (R DEVELOPMENT CORE TEAM, 2011), associated with the Vegan package (OKSANEN et al., 2011), and also the PAST free software (HAMMER et al., 2001).

\section{RESULTS}

The limnological parameters measured in the reservoir and the rainfall data are shown in Figure 2. The lowest depth (Fig. 2A) registered was 2 meters at point 8 in November of 2016, and the deepest point measured was $13.5 \mathrm{~m}$ at point 1 in March 2017. The transparency (Fig. 2B) varied between 0.5 and 2.7 meters with the lowest value at point 8 and the highest at point 2 .

For the electrical conductivity (Fig. $2 \mathrm{C}$ ), the lowest value was $7.3 \mu \mathrm{S} \mathrm{cm}^{-1}$ in the intermediate climatological station and values above $200 \mu \mathrm{S} \mathrm{cm}^{-1}$ occurred in the rainy season. The results for DO (Fig. 2E) demonstrate a tendency for reduction of DO during the rainy season. The highest value recorded was 11.67 $\mathrm{mg} \mathrm{L}^{-1}$ at P4 during the transition season, and the lowest value was $1.6 \mathrm{mg} \mathrm{L}^{-1}$ at $\mathrm{P} 3$ during the dry season. The lowest pH (Fig. 2F) value recorded during the study period was 4.59 at point 5 during August, and the highest value was 7.9 at point 1 during November.

The concentration of ammonia showed a tendency to increase in the rainy season (Fig. 2I) and its highest observed value was $1.03 \mathrm{mg} \mathrm{L}^{-1}$ in P1, while the lowest observed value was $0.05 \mathrm{mg} \mathrm{L}^{-1}$ in P7 in the dry season. The highest turbidity values observed at P8 were 30.2 NTU (Fig. 2G), for nitrate $4.54 \mathrm{mg} \mathrm{L}^{-1}$ (Fig. 2J) and silica $16.18 \mathrm{mg} \mathrm{L}^{-1}$ (Fig. 2K) in the intermediate (transition) climatological station and beginning of the rainy season, and this is a reflection of regional characteristics of the source of the Curuá-Una River.

The analysis of BOD (Fig. 2H) showed that this variable had a behavior inverse to that of DO wherein it had higher values during the rainy season (maximum value of $9.97 \mathrm{mg} \mathrm{L}^{-1}$ at P6). It is important to emphasize that this sampling point receives water from the principal tributaries of the reservoir.

The highest total phosphorus (Fig. 2M) concentrations registered in our study were P8 $\left(14.7 \mu \mathrm{g} \mathrm{L}^{-1}\right)$ and P6 $\left(6.9 \mu \mathrm{g} \mathrm{L}^{-1}\right)$ in the dry season. The variation in chlorophyll-a (Fig. $2 \mathrm{~N}$ ) was entirely seasonal with greater values in the dry season ( $\mathrm{P} 2=10.47 \mu \mathrm{g} \mathrm{L}-1$; $1=15.4 \mu \mathrm{g} \mathrm{L}^{-1} ; \mathrm{P} 3=20.94 \mu \mathrm{g} \mathrm{L}^{-1}$ ). Minimum and maximum rainfall values (Fig. O) Of 15 and $393 \mathrm{~mm}$ respectively were observed over the studied period.

In Figure 3 there is a pattern wherein the samples are clearly seasonally (rainy, dry, transition) separated between collections during the 12 months, and this dispersion tends to have a strong interannual variation in the reservoir, however there was no evident spatial pattern between the samples.

The PCA (Fig. 3) revealed that just the first two axes are significant, and that the variation explained by these axes was $51.74 \%$ for the limnological and rainfall data. Table 1 shows the individual contributions (loadings) of the significant limnological variables that were tested using bootstrapping.

In the Canonical Redundancy Analysis (RDA), the limnological variables were highly influenced by the spatial and temporal explanatory variables ( $R D A, F=12.9, p=0.001$ ) and that the total variation explained by 
these explanatory variables was $66 \%$.
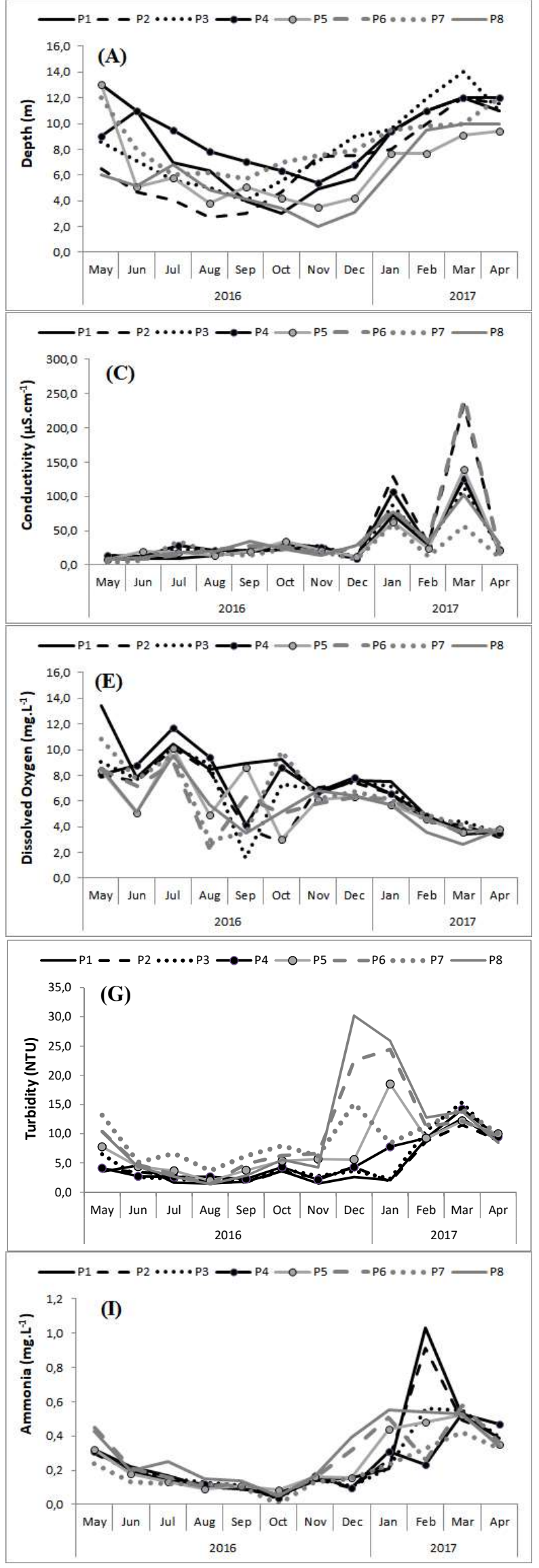
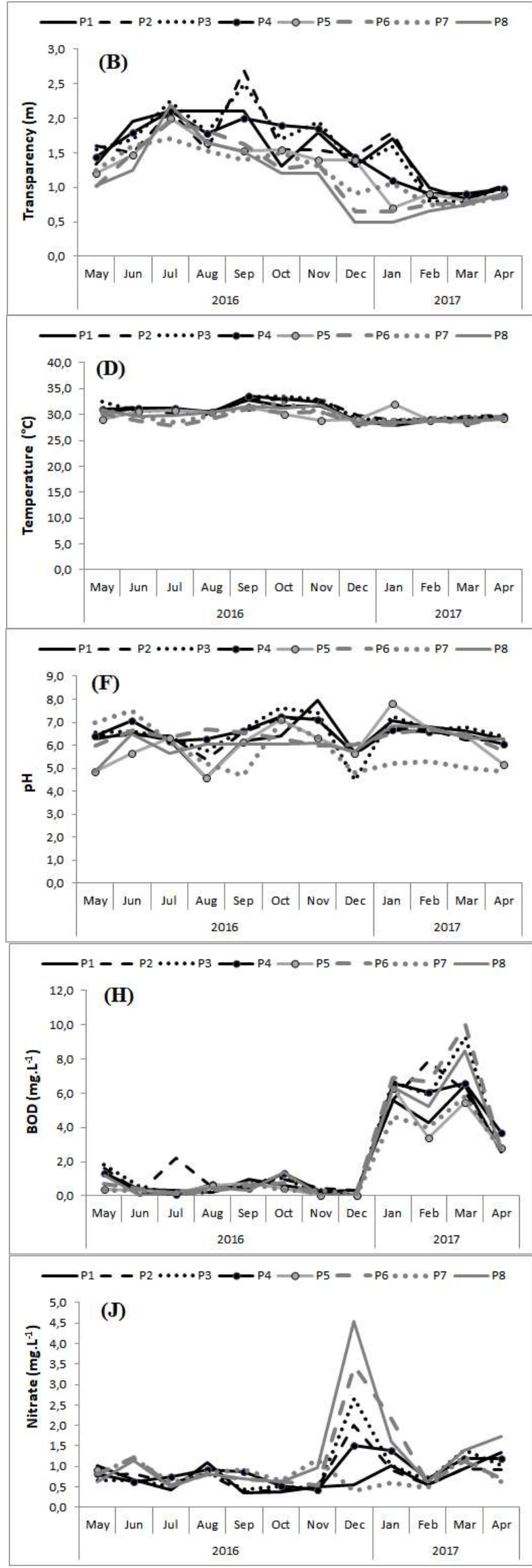

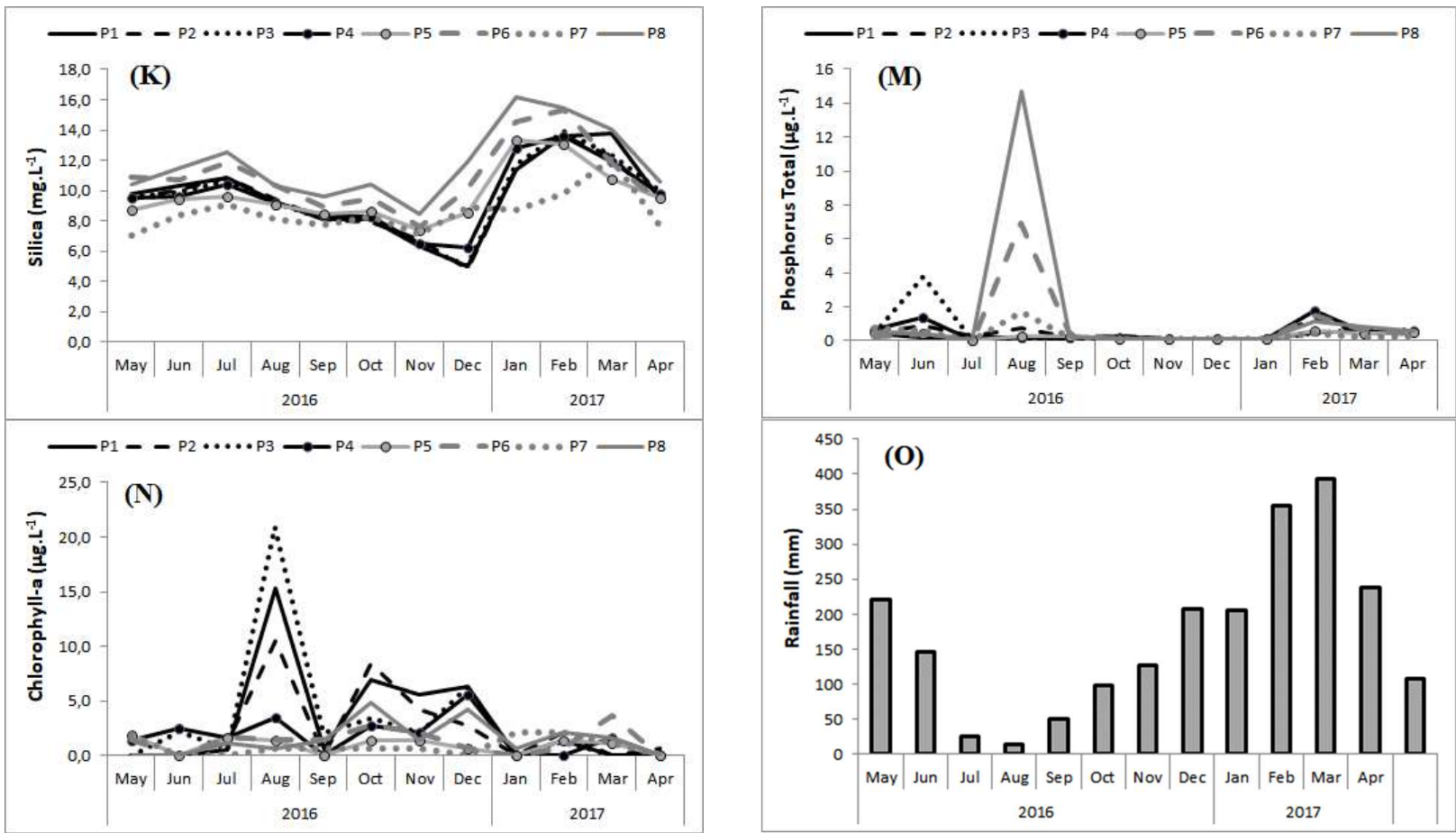

Figure 2: Variation of limnological variables and rainfall at the Curuá-Una reservoir between May 2016 and April 2017.

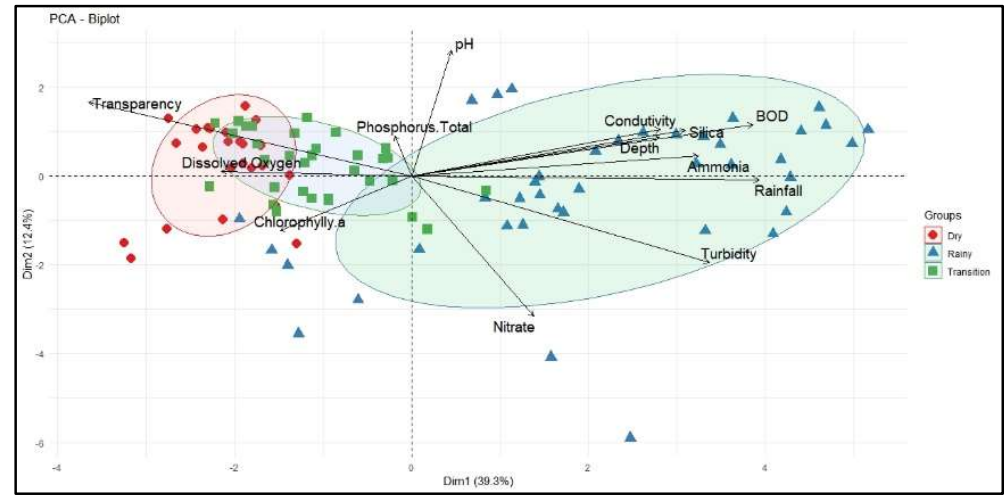

Figure 3: Diagram of the ordination of the of the principal components analysis for the limnological variables in the Curuá-Una reservoir.

Table 1: Individual contribution (Loadings) of the environmental variables (original variables) for the first two axes generated by the Principal Components Analysis (PCA). The Loadings that significantly contributed using bootstrapping ( $n=9999)$ for each axis are highlighted in bold.

\begin{tabular}{lll}
\hline Variables & Axis 1 & Axis 2 \\
\hline Depth & $\mathbf{0 . 2 8 0 4}$ & 0.1577 \\
Transparency & $-\mathbf{0 . 3 6 5 3}$ & $\mathbf{0 . 2 9 7 8}$ \\
Conductivity & $\mathbf{0 . 2 8 1 8}$ & 0.1889 \\
Dissolved Oxygen & $-\mathbf{0 . 2 1 4 9}$ & 0,0204 \\
pH & 0.0455 & $\mathbf{0 . 5 0 7 4}$ \\
Turbidity & $\mathbf{0 . 3 3 6 9}$ & $\mathbf{- 0 . 3 4 6 2}$ \\
BOD & $\mathbf{0 . 3 8 6 3}$ & $\mathbf{0 . 2 0 7 1}$ \\
Ammonia & $\mathbf{0 . 3 2 5 0}$ & 0.0819 \\
Nitrate & 0.1381 & $-\mathbf{0 . 5 6 1 4}$ \\
Silica & $\mathbf{0 . 3 0 9 5}$ & 0.1841 \\
Phosphorus Total & 0.0190 & 0.1631 \\
Chlorophyll-a & $-\mathbf{0 . 1 4 2 6}$ & -0.2177 \\
Rainfall & $\mathbf{0 . 3 9 3 3}$ & 0.0147 \\
\hline Pincipal Components & Eigenvalue & \% variance \\
\hline 1 & 5.111 & 39.3230 \\
2 & 1.6143 & 12.4180 \\
\hline
\end{tabular}

The explanatory variables selected by the forward selection method using the Monte Carlo test 
selected the dry and rainy periods as temporal variables. The variable transition showed colinearity with the variable dry season in spite of explaining a significant portion of the variability of the limnological data, and this period was not included in the analysis for the partition of variance.

The spatial descriptors generated 5 PCNMs from which just PCNM1 was selected, meaning that the longitudinal (vertical) distribution of the limnological variables occurs along a larger spatial scale associated with PCNM1, which has a scale of 26.7 kilometers, and which means that the limnological variables vary on average every 26.7 kilometers. The Dummy variables of $A 1, A 2$ and $A 3$ areas, none of them were selected.

The analysis done for the partition of the variance showed $66 \%$ of the variance is explained by the spatial-temporal parameters, and that $34 \%$ of the variance was not captured in this study, divided into time (56\%), spatial (10\%), temporal and spatial $(0 \%)$, and residual (34\%). Within the percentage explained only by time, the largest contribution was from the rainy season (50\%) followed by the dry season (6\%).

In Table 2 the limnological variables present significant differences for the hydroperiod factor (Seasons: Rainy, transition and dry) with the exception of temperature, total phosphorus, and chlorophyll-a. With the exception of transparency and turbidity, the other variables did not present a significant difference for the factor Areas (A1: P1 e P2; A2: P3, P4 e P5; A3: P6, P7 e P8), and no variables had a significant interaction between the two factors.

Table 2: Results for the two-way ANOVA and the Tukey post hoc test for comparison of means, considering Factor 1 as the temporal variables (Hydroperiod), Factor 2 as the spatial variables (Areas) and the interaction enters the variables of time and space (Hydroperiod $x$ Areas). Significant effects $(p<0.05)$ are in bold.

\begin{tabular}{|c|c|c|c|c|c|c|c|c|}
\hline \multirow{2}{*}{ Variable } & \multicolumn{2}{|c|}{ Hydroperiod } & \multicolumn{2}{|l|}{ Areas } & \multicolumn{2}{|c|}{ Interaction } & \multicolumn{2}{|c|}{ Mean comparisons } \\
\hline & $\mathrm{F}$ & $\mathrm{p}$ & $\mathrm{F}$ & $\mathrm{p}$ & $\mathrm{F}$ & $p$ & Hydroperiod & Areas \\
\hline Depth & 5.855 & 0.004 & 2.867 & 0.06225 & 0.680 & 0.6072 & $\mathrm{Ch}>\mathrm{Tr}>\mathrm{Se}$ & - \\
\hline Transparency & 68.78 & $<0.0001$ & 14.29 & $<0.0001$ & 0.561 & 0.6915 & $\mathrm{Se}>\mathrm{Tr}>\mathrm{Ch}$ & $\mathrm{A} 1=\mathrm{A} 2>\mathrm{A} 3$ \\
\hline Conductivity & 18.46 & $<0.0001$ & 0.149 & 0.861 & 0.296 & 0.8796 & $\mathrm{Ch}>\mathrm{Tr}=\mathrm{Se}$ & - \\
\hline Temperature & 0.35 & 0.8753 & 0.463 & 0.525 & 1.046 & 0.3883 & - & - \\
\hline Dissolved Oxygen & 4.284 & 0.0168 & 1.43 & 0.2449 & 0.709 & 0.5877 & $\mathrm{Tr}=\mathrm{Se}>\mathrm{Ch}$ & - \\
\hline $\mathrm{pH}$ & 3.71 & 0.0271 & 2.388 & 0.098 & 0.525 & 0.7175 & $\mathrm{Tr}=\mathrm{Ch}>\mathrm{Se}$ & - \\
\hline Turbidity & 39.1 & $<0.0001$ & 15.39 & $<0.0001$ & 0.980 & 0.4226 & $\mathrm{Ch}>\mathrm{Tr}=\mathrm{Se}$ & $\mathrm{A} 1=\mathrm{A} 2>\mathrm{A} 3$ \\
\hline BOD & 45.47 & $<0.0001$ & 0.093 & 0.9116 & 0.047 & 0.9957 & $\mathrm{Ch}>\mathrm{Tr}=\mathrm{Se}$ & - \\
\hline Ammonia & 11.7 & $<0.0001$ & 0.079 & 0.9245 & 0.118 & 0.9758 & $\mathrm{Ch}>\mathrm{Tr}>\mathrm{Se}$ & - \\
\hline Nitrate & 10.76 & $<0.0001$ & 1.704 & 0.1881 & 0.597 & 0.6657 & $\mathrm{Ch}>\mathrm{Tr}=\mathrm{Se}$ & - \\
\hline Silica & 7.19 & 0.0013 & 0.327 & 0.7217 & 0.036 & 0.9974 & $\mathrm{Ch}>\mathrm{Tr}>\mathrm{Se}$ & - \\
\hline Total phosphorus & 0.5015 & 0.6074 & 0.216 & 0.8062 & 1.397 & 0.2417 & - & - \\
\hline Chlorophyll-a & 1.667 & 0.1947 & 1.901 & 0.1556 & 0.907 & 0.4635 & - & - \\
\hline
\end{tabular}

Legend: $\mathrm{Ch}=$ rainy season; $\mathrm{Tr}=$ transition; $\mathrm{Se}=$ dry season; $\mathrm{A} 1$ = Area $1 ; \mathrm{A} 2$ = Area 2 and A3= Area 3.

\section{DISCUSSION}

The results of depth and transparency were similar to those of Junk et al. (1981), and Vieira et al. (1999) who measured a water transparency of $0.6 \mathrm{~m}$ upriver from the Curuá-Una dam, and within the reservoir values between 1.6 and $2.3 \mathrm{~m}$ were registered without a large fluctuation between the study years.

The values of electrical conductivity between the intermediate and dry seasons were similar to those of Junk et al. (1981) (11-28.4 $\left.\mu \mathrm{S} \mathrm{cm}^{-1}\right)$, Vieira et al. (1999) (10.9-25.7 $\left.\mu \mathrm{S} \mathrm{cm}^{-1}\right)$ and Gunkel et al. (2003) observed mean values of $25-29.5 \mu \mathrm{S} \mathrm{cm}^{-1}$. However, the values above $100 \mu \mathrm{sm}^{-1}$ observed in the present study coincide in the period of the rainy season and may be associated to the increase of human occupation around 
A multivariate approach to analyze the spatial-temporal variation of limnological parameters of the reservoir of the Curuá-Una hydroelectric

the reservoir, which consequently results in a higher sediment load in the rainy season. According to Gunkel et al. (2003), the sub-catchment basin of the Curuá-Una river presents a high ionic enrichment $\left(40 \mu \mathrm{S} \mathrm{cm}^{-1}\right)$ caused by erosion of anthropic origin and by the natural process of the environment. These authors estimated that the increment of sediment by erosion occurs at a rate equivalent to $0.7 \mathrm{~m}$ of sediment entry every 10 years, which could significantly reduce the operational life of the Curuá-Una reservoir.

The Dissolved Oxygen data from the present study are similar to those registered by Junk et al. (1981) and Vieira et al. (1999) who observed a reduction in DO as the collection points neared the dam (5 - $4 \mathrm{mg} \mathrm{L}^{-1}$ at collection points in the river and less than $1-0.5 \mathrm{mg} \mathrm{L}^{-1}$ near the dam). The study by Gunkel et al. (2003), who studied the reservoir approximately 20 years after its construction, observed a high rate of oxygen in the epilimnion $(0-3 \mathrm{~m})$ of $5.5 \mathrm{mg} \mathrm{L}^{-1}$, as well as anoxic conditions in the hypolimnion at $>8 \mathrm{~m}$ depth.

Regarding this $\mathrm{pH}$ variation, the values remained similar to the mean values observed by Junk et al. (1981) (pH 4.1-5.4), Vieira et al. (1999) (pH 4.6-6.5) and Gunkel et al. (2003) (pH 5.2-6.8). It is noticed that there is a tendency of increase in the maximum values in comparison with the previous data recorded in the literature, and this hypothesis was raised due to the presence of ammonia $\left(\mathrm{NH}_{3}\right)$ of anthropogenic origin and the cattle activity observed in some collection stations.

It is noticed that the points $\mathrm{P} 1$ and $\mathrm{P} 2$ the ammonia values are similar, and in this area of the reservoir the characteristics of the lentic environment is evidenced by the nearness of the dam and the longer retention time of the water. This higher concentration of ammonia near the dam comes from the biological oxidation product of ammoniacal nitrogen (RICHTER et al., 2007). In addition, it is important to point out that high concentrations of ammonia are a pollutant source indicator, since it is the initial product of the organic nitrogen residues decomposition (MANAHAM, 2013).

With respect to turbidity, Vieira et al. (1999) observed the diluting effect of rainfall on the Curuá-Una River (P8) is attenuated by leaching and weathering of the more fertile soils located at the river's source. Junk et al. (1981) stated that the Curuá-Una River in its upper course crosses carboniferous terrain that is geochemically rich, while the basins of the Moju and Mojuí rivers (P7) are predominantly situated on Tertiary geologic formations that are more acidic and poorer in nutrientes and minerals.

The BOD is a parameter that is directly and indirectly related to the quantity of respirable organic matter present in the water and the quality of an aquatic ecosystem, and is also a potential indicator of emissions of greenhouse gases from rivers to the atmosphere (WARD et al., 2013). The high value for BOD during the rainy season could be related to the intense activities of the rural settlements located on the margins of the reservoir that have pastures and agricultural fields. These settlements are the result of an increasing population density in the region of the tributaries of the Moju and Mojuí rivers registered since the decade of the 1990s (GUNKEL et al., 2003).

This high concentration of total phosphorus in P8 and soon after in P6 in August is likely to be associated with the richer soil of the Curuá-Una river in its upper course. Junk et al. (1981) reported values ranging from 32 to $43.4 \mu \mathrm{g} \mathrm{L}^{-1}$. Gunkel et al. (2003) reported mean values of total phosphorus in epilimnion 
A multivariate approach to analyze the spatial-temporal variation of limnological parameters of the reservoir of the Curuá-Una hydroelectric

$0.021 \mathrm{mg} \mathrm{L}^{-1}$ and in hypolimnion $0.033 \mathrm{mg} \mathrm{L}^{-1}$. Comparing our results with those reported in the literature, there is a downward trend over the years, and this information is demonstrated by Gunkel et al. (2003), who considered low the nutrient levels found in their study and they observed moderate eutrophic conditions after 23 years of damming. More recent studies indicate that the reservoir fits between ultraoligotrophic and mesotrophic, showing a tendency to increase in its trophic state in the dry season with possible implications for water quality, but at acceptable levels, in most cases (SANTOS et al., 2018).

In regard to the peaks of total phosphorus concentrations in P3, P4 and P7, they may be associated with the increasing soil leaching in the region, caused by the lack of riparian vegetation protection due to the intensive anthropic action in the reservoir environment. It is resulted of the undergoing changes in the region hydrographic microbasins caused by agricultural expansion and the soil use in the last three decade, which may be contributing to the microbasins sedimentation and its nutrient input (AGUIAR et al., 2014; SILVA et al., 2017).

Regarding chlorophyll-a, considering that the highest peaks occurred in the central points toward the dam, having its flow controlled to develop a lentic environment in the dry season, and it contributed to transparency (Fig. 2B) values increasing, so to the expansion of the euphotic zone favoring the photosynthetic activity. And, combined with the lower loss of chemical and biological material by the turbines and spillways upstream of the reservoir, it may have stimulated the phytoplankton growth rate, which explains the higher concentrations of chlorophyll found in this period and in this area. Another event that could be associated with the chlorophyll peaks in the vicinity of the dam is the wind action inlow water level period. According to Naselli-Flores et al. (2003), small reservoirs in low water level period with high residence time of the water suffer wind direct action. This climatological forcing, although not measured in the current study, could have been indirectly influenced the chlorophyll-a variability in the Curuá-Una reservoir, since sediments of shallow lakes can liberate phosphorus that is available in aerobic conditions through resuspension of sediment by the wind, presumably with greater rates of photosynthesis and primary production (BOSTRÖM et al., 1982; SØNDERGAARD et al., 2003).

The rainfall data were very similar to those of Vieira et al. (1999) who highlighted the fact that the response in the reservoir is simultaneous and directly linked to rainfall, and occurs during periods of low water between June and December, and also during periods of high water between January and May, according to the data collected by the Curuá-una HP. This was confirmed by Vale et al. (2016), who demonstrated the existence of a climatic pattern in reservoirs that have a well-defined seasonality with January to May being the rainy season and July to December the dry season.

The results in Table 1 and Figure 3 show that the first axis (PC) explained 39.3\% of the variation forming a gradient of transparency, dissolved oxygen, and chlorophyll-a and had a negative coefficient. This axis also represents a gradient with positive coefficients for Depth, conductivity, turbidity, BOD, ammonia, silica, and rainfall, which clearly reflect the effect of the rainy season on the reservoir. This fact can be associated with the surface flow caused by the anthropic action in the reservoir surroundings. The second 
axis explains $12.4 \%$ and forms a gradient of transparency, $\mathrm{pH}$, turbidity, $\mathrm{BOD}$ and nitrate. Among these variables, $\mathrm{pH}$ and nitrate present the greatest contributions to this axis. The $\mathrm{pH}$ is apparently not influenced seasonally, as for the nitrate its greater variability is influenced by the rainy season.

The results of the spatial descriptors (PCNM) show that the distribution of these variables is homogeneous in the lentic environment, as also observed by Junk et al. (1989) for almost all the parameters analyzed in the vertical direction in their study.

The multivariate approach (PCA/RDA and partition of variance) used in this study generated results that indicate that the sources of interannual variation result from climate forcings (rainfall), and that these forcings are the principal source of variation which causes periods of mixture and transport of sediments that can interfere in the quality of water in the reservoir. This seasonal/interannual variation is one of the key factors that controls the structure of aquatic communities through diverse ecological mechanisms that include limitations to abiotic factors and biotic interactions (JUNK et al., 1989; BAYLEY, 1991). Junk et al. (1989) was the first that emphasized the strict relationship between the effect of interannual seasonality and abiotic and biotic components when they proposed the concept of Pulse and Inundation.

The rest of the variation that was not explained could be associated to anthropic action such as occupation of the soil, pasture Aguiar et al. (2014), Silva et al. (2017), and operations within the Curuá-Una HP cited by Gunkel et al. (2003), concomitant with deforestation and the expansion of agricultural activities in the region of western Pará. Furthermore, the variations of the interannual precipitation patterns in the Amazon may have some relation to the variability of the limonological variables of the reservoir. These interannual patterns of precipitation in Amazonia that are controlled by the Pacific Southern Oscillation (EI Niño and La Niña), and also by the increase in temperature of the surface of the Atlantic Ocean, directly affect the water balance of the micro basin of the Curuá-Una (FU et al., 2013; MARENGO et al., 2013; VALE et al., 2016).

The ANOVA results confirm the hypotheses suggested by the multivariate analysis that there is a temporal pattern for the limnological variables studied in this research. The comparisons of the averages of the factor treatments using the Tukey post hoc test are shown in Table 2. The largest averages in this table occur in the rainy season and are for the variables depth, conductivity, turbidity, BOD, ammonia, nitrate, and silica. However, the largest averages for transparency, $\mathrm{DO}$, and $\mathrm{pH}$ occur in the dry and transition seasons.

With respect to the comparison of the areas, there were no significant differences between the limnological variables with the exception of transparency and turbidity (Tab. 2). The average values for transparency and turbidity did not show significant differences between Areas 1 and 2, and these values were lowest for Area 3.

\section{CONCLUSIONS}

The results of this study suggest that the seasonal hydrological affect is responsible for $56 \%$ of the variability, while the spatial parameters explained just $10 \%$ of the results. The residues, that is, the part that 
still has to be explained, we believe it can be associated with other factors already discussed here, such as anthropic action and climatic factors. Changes through time are sufficient to alter biological processes, generating a pattern of functional redundancy during the rainy season when environmental conditions are more turbulent.

It is important to emphasize that it is necessary to undertake an annual monitoring campaign to capture the variation of an entire cycle, principally in order to better understand the reduction in the concentration of nutrients in comparison with previous studies wherein a moderate eutrophic condition was reported 23 years after dam construction and the creation of the reservoir.

The necessity of this monitoring and its continuity throughout the years to come is evident since the Curuá-Una HP is the first reservoir constructed in the central Amazon. Future studies should not be limited to just physical and chemical variables, but ecological communities and interactions between water and substrates and water and climatological variables should also be included.

ACKNOWLEDGEMENTS: The authors thank the research program PRO-AMAZÔNIA through grant № 23038.009453/2013-01, the company Centrais Elétricas do Norte do Brasil S.A (ELETRONORTE), and the Curuá-Una HP for the logistical support, and also the Doctorate Program in Society, Nature, and Development (PPGSND) of the Federal University of Western Pará.

\section{REFERENCES}

AGOSTINHO, A. A.; GOMES, L. C. O.. Manejo da pesca em reservatórios da bacia do alto rio Paraná: avaliação e perspectivas in: NOGUEIRA, M. G.; HENRY, R.; JORCIN, A.. Ecologia de reservatórios: impactos potenciais, ações de manejo e sistemas em cascata. 2 ed. São Carlos: RiMa, 2006. p.23-55.

AGUIAR, C. P. O.; PELEJA, J. R. P.; SOUSA, K. N. S.. Qualidade da água em microbacias hidrográficas com agricultura nos municípios de Santarém e Belterra, Pará. Revista Árvore, v.38, n.6, p.983-992, 2014. DOI:

http://doi.org/10.1590/S0100-67622014000600003

ANEEL. Agência Nacional de Energia Elétrica. Banco de Informações de geração. Brasília: ANEEL, 2009.

BAYLEY, P.. The flood pulse advantage and the restoration of river-floodplain systems. Regulated Rivers: Research \& Management, v.6, p.75-86, 1991. DOI: http://doi.org/10.1002/rrr.3450060203

BORCARD, D.; LEGENDRE, P. All-scale spatial analysis of ecological data by means of principal coordinates of neighbour matrices. Ecol Model, V.153, p.51-68, 2002. DOI: http://doi.org/10.1016/S0304-3800(01)00501-4

BORCARD, D.; LEGENDRE, P.; DRAPEAU, P.. Partialling out the spatial component of ecological variation. Ecology, v.73, p.1045-1055, 1992. DOI: http://doi.org/10.2307/1940179/abstract

BOSTRÖM, B.; JANSSON, M.; FORSBERG, C.. Phosphorus release from lake sediments. Arch. Hydrobiol. Beih. Ergebn. Limnol., v.18, p.5-59, 1982.
DIEGUES, A. C. S.. Etnoconservação da Natureza: enfoques alternativos. In: DIEGUES, A. C.. Etnoconservação: novos rumos para a proteção da natureza nos trópicos. 2 ed. São Paulo: Hucitec, 2000. p.1-46.

FARIA, A. M. M.. Hidroelétricas Amazônicas: Fontes energéticas apropriadas para o desenvolvimento regional?. Paper do NAEA, v.90, p.1-37, 2006.

FEARNSIDE, P. M.. Environmental and social impacts of hydroelectric dams in Brazilian Amazonia: Implications for the aluminum industry. World Development, v.77, p.48-65, 2016. DOI: http://doi.org/10.1016/j.worlddev.2015.08.015

FISCH, G.; MARENGO, J. A.; NOBRE, C. A.. Uma Revisão Geral Sobre o Clima da Amazônia. Acta Amazonica, v.28, p.101126, 1998.

FU, R.; YIN, L.; LI, W.; ARIAS, P. A.; DICKINSON, R. E.; HUANG, L.; FERNANDES, K.; LIEBMANN, B.; FISHER, R.; MYNENI, R. B.. Increased dry-season length over southern Amazonia in recent decades and its implication for future climate projection. Proceedings of the National Academy of Science, v.110, p.18110-18115, 2013. DOI: http://doi.org/10.1073/pnas.1302584110

GRIFFITH, D. A.; PERES-NETO, P. R.. Spatial modelling in ecology: The flexibility of eigenfunction spatial analyses. Ecology, v.87, n.10, p.2603-2613, 2006.

GUNKEL, G.; LANGE, U.; WALDE, D.; ROSA, J. W. C.. The environmental and operational impacts of Curuá-Una, a reservoir in the Amazon region of Pará, Brazil. Lakes \& Reservoirs: Research and Management, v.8, p.201-216, 2003. 
HAMMER, O.; HAPER, D. A. T.; RYAN, P. D.. PAST: Paleontological Statistics software package for education and data analisys. Paleontologia Electronica. v.4, p.1-9, 2001.

JUNK, W. J.; BAYLEY, P. B.; SPARKS, R. E.. The flood pulse concept in river: floodplain systems. Special Publication of the Canadian Journal of Fisheries and Aquatic Sciences, v.106, p.10-127, 1989.

JUNK, W. J.; ROBERTSON, B. A.; DARWICH, A. J.; VIEIRA, I.. Investigações limnológicas e ictiológicas em Curuá-Una, a primeira represa hidroelétrica da Amazônia Central. Acta Amazonica, v.11, n.4, p.689-716, 1981. DOI: http://doi.org/10.1590/1809-43921981114689

LEGENDRE, P.; LEGENDRE, L.. Numerical Ecology. 3 ed. Elsevier, 2012.

MANAHAM, S. E.. Química Ambiental. 9 ed. Porto Alegre. Bookman Ltda., 2013.

MARENGO, J. A.; ESPINOZA, J. C.. Extreme seasonal droughts and floods in Amazonia: causes, trends and impacts. International Journal of Climatology, v.36, p.1033-1050, 2016. DOI: http://doi.org/10.1002/joc. 4420

MORETTO, E. V.; GOMES, C. S.; ROQUETTI, D. R.; JORDÃO, C. O.. Histórico, tendências e perspectivas no planejamento espacial de usinas hidrelétricas brasileiras: a antiga e atual fronteira Amazônica. Revista Ambiente \& Sociedade, v.15, n.3, p.141-164, 2012. DOI: http://doi.org/10.1590/S1414753X2012000300009

NASELLI-FLORES, L.; BARONE, R.. Steady-state assemblages in a Meditarranean hyperthophic reservoir. The role of Microcystis ecomorphological variability in a maintaining an apparent equilibrium. Hydrobiologia, v.502, p.133-143, 2003. DOI:

http://doi.org/10.1023/B:HYDR.0000004276.11436.40

OKSANEN, J.; BLANCHET, F. G.; KINDT, R.; LEGENDRE, P.; O'HARA R. B.; SIMPSON, G. L.. Vegan: Community Ecology Package. (R package version 1.17-6). 2011.

OLIVEIRA, E. F.; GOULART, E. E.. Distribuição espacial de peixes em ambientes lênticos: interação de fatores. Acta Scientiarum, v.22, p.445-453, 2000. DOI: http://doi.org/10.4025/actascibiolsci.v22i0.2963

PERES-NETO, P. R.; JACKSON, D. A.; SOMERS, K. M.. Giving meaningful interpretation to ordination axes: assessing the significance of eigenvector coefficients in principal component analysis. Ecology v.84, p.2347-2363, 2003. DOI: http://doi.org/10.1890/00-0634/abstract

PERES-NETO, P. R.; LEGENDRE, P.; DRAY, S.; BORCARD, D.. Variation partitioning of species data matrices: Estimation and comparison of fractions. Ecology, v.87, p.2614-2625, 2006.
R DEVELOPMENT CORE TEAM. R: A language and environment for statistical computing. Vienna: R Foundation for Statistical Computing, 2011.

RICHTER, E. M.; FORNARO, A.; LAGO, C. L.; ANGNES, L.. Avaliação da composição química de águas do Sistema Guarapiranga: estudo de caso nos anos de 2002 e 2003. Química Nova, v.30, n.5, p.1147-1152 2007. DOI: http://doi.org/10.1590/S0100-40422007000500018

SANTOS, E. S.; CUNHA, A. C.; CUNHA, H. F. A.. Usina hidrelétrica na Amazônia e impactos socioeconômicos sobre os pescadores do município de Ferreira Gomes-Amapá. Ambiente \& Sociedade, v.20, n.4, p.197-214, 2017. DOI: http://doi.org/10.1590/1809-4422asoc0088r2v2042017

SANTOS, P. R. B.; ZARZAR, C. A.; SOUSA, N. S. S.. Avaliação do estado trófico atual do reservatório da Usina Hidrelétrica de Curuá-Una, a mais antiga represa construída na Amazônia central. Biota Amazônia, v.8, n.4, p.45-48, 2018. DOI: http://doi.org/10.18561/2179-

5746/biotaamazonia.v8n4p45-48

SILVA, R. G. C.; CONCEIÇÃO, F. S.. Agronegócio e campesinato na Amazônia brasileira: transformações geográficas em duas regiões nos estados de Rondônia e Pará. GEOgraphia, v.19, n.41, p.54-72, 2017. DOI: http://doi.org/10.22409/geographia.v19i41.1008

SØNDERGAARD, M.; JENSEN, J. P.; JEPPESEN, E.. Role of sediment and internal loading of phosphorus in shallow lakes. Hydrobiologia, v.506, p.135-145, 2003. DOI: http://doi.org/10.1023/B:HYDR.0000008611.12704.dd

STRICKLAND, J. D. H.; PARSONS, T. R.. A practical handbook of seawater analysis Bull. Fish. Res. Bd Can, v.167, p.1-311, 1968. DOI: http://doi.org/10.1002/iroh.19700550118

TUNDISI, T. M.; TUNDISI, J. G.. Limnologia. Oficina De Textos, 2008.

VALE, R. S.; GOMES, A. C. S.; SANTANA, R. A. S.; TÓTA, J.; MILLER, S. D.; SOUSA, R. A. F.. Hydroclimatic variables associated with El Nino and La Nina events at the Curuá-Una hydroelectric reservoir, Central Amazonia. Acta Amazônica, v.46, n.3, p.303-308. 2016. DOI: http://doi.org/10.1590/1809-4392201600083

VIEIRA, I.; DARWICH, A. J.. Sinecologia da ictiofauna de Curuá-Una, Amazônia: Características hidroquímicas, Climáticas, vegetação e peixes. Acta Limnologica Brasiliensia, v.11, n.2, p.41-64, 1999.

WARD, N. D.; KEIL, R. G.; MEDEIROS, P. M.; BRITO, D. C.; CUNHA, A. C.; DITTMAR, T.; YAGER, P. L.; KRUSCHE, A. V.; RICHEY, J. E.. Degradation of terrestrially derived macromolecules in the Amazon River. Nature Geoscience, v.6, n.6, p.1-4, 2013. DOI: http://dx.doi.org/10.1038/ngeo1817

A CBPC - Companhia Brasileira de Produção Científica (CNPJ: 11.221.422/0001-03) detém os direitos materiais desta publicação. Os direitos referem-se à publicação do trabalho em qualquer parte do mundo, incluindo os direitos às renovações, expansões e disseminações da contribuição, bem como outros direitos subsidiários. Todos os trabalhos publicados eletronicamente poderão posteriormente ser publicados em coletâneas impressas sob coordenação da Sustenere Publishing, da Companhia Brasileira de Produção Científica e seus parceiros autorizados. Os (as) autores (as) preservam os direitos autorais, mas não têm permissão para a publicação da contribuição em outro meio, impresso ou digital, em português ou em tradução. 